\title{
Efektifitas Kinerja Instalasi Pengolahan Air Limbah (IPAL) Industri Gula di Kabupaten Kediri dan Kabupaten Sidoarjo
}

\section{Efectiveness Performance of Sugar Cane Industry Waste Water Treatment (WWTP) in Kediri and Sidoarjo Regency}

\author{
ERRY IKA RHOFITA, ALDENTIO EMIR RUSSO \\ Program Studi Teknik Lingkungan, Fakultas Sains dan Teknologi, UIN Sunan Ampel Surabaya, \\ Jalan A. Yani No 117 Surabaya 60237 \\ Email: erryikarhofita@uinsby.ac.id
}

\begin{abstract}
Wastewater from sugar industries has complex characteristics and depends on the production capacity. The main aim of this study is to determine the effectiveness of the waste water treatment processes (WWTP) of two sugar factories PG. Kediri and PG. Sidoarjo in reducing $\mathrm{pH}, \mathrm{BOD}, \mathrm{COD}$, and TSS during year 2016 and 2017. Wastewater influents in both factories exceeded the water quality standards of Ministry of Environment Regulation Number 5 Year 2014. After treatments, water quality parameters of the effluents including $\mathrm{pH}, B O D, C O D$ and TSS were significantly decreased. The effectiveness of the PG Kediri WWTP in reducing BOD, COD and TSS was $98.52 \%$; $98.47 \%$ and $91.51 \%$ respectively. The effectiveness of PG Sidoarjo WWTP in reducing BOD, COD and TSS was 5-20\% lower than that of PG. Kediri.
\end{abstract}

Keywords: effectiveness performance, WWTP, sugar industry, wastewater

\begin{abstract}
ABSTRAK
Limbah cair yang dihasilkan oleh industri gula memiliki karakteristik yang kompleks dan bergantung pada kapasitas produksi. Pengolahan limbah cair dilakukan secara fisika dan biologi untuk mengurangi konsentrasi bahan pencemar yang menjadi permasalahan lingkungan. Tujuan dari penelitian ini adalah untuk mengetahui efektifitas kinerja IPAL di PG. Kediri dan PG. Sidoarjo dalam menurunkan konsentrasi $\mathrm{pH}, \mathrm{BOD}, \mathrm{COD}$ dan TSS selama tahun 2016 dan 2017. Sebelum pengolahan air limbah memiliki konsentrasi tinggi melebihi ambang batas baku mutu air limbah yang ditetapkan oleh Peraturan Menteri Lingkungan Hidup RI No. 5 Tahun 2014. Setelah dilakukan pengolahan terjadi penurunan konsentrasi $\mathrm{pH}, \mathrm{BOD}, \mathrm{COD}$, dan TSS secara signifikan yang diukur di bagian outlet IPAL. Besarnya efektifitas kinerja IPAL di PG Kediri dalam menurunkan konsentrasi BOD, COD, dan TSS sebesar 98,52\%; 98,47\%; dan 91,51\%. Berbeda dengan nilai efektifitas kinerja IPAL di PG Sidoarjo yang lebih rendah 5 sampai $20 \%$ dari efektifitas PG. Kediri.
\end{abstract}

Kata kunci: efektifitas kinerja, industri gula, IPAL, limbah cair

\section{PENDAHULUAN}

\subsection{Latar Belakang}

Industri gula merupakan usaha dan/atau kegiatan di bidang pengolahan tebu menjadi gula beserta turunannya yang digunakan untuk konsumsi manusia dan pakan ${ }^{(1)}$. Sedangkan proses produksi gula yang merupakan proses mengubah tebu (bahan baku utama) menjadi nira melalui beberapa tahapan seperti proses ekstraksi, pembersihan kotoran, penguapan, kritalisasi, afinasi, karbonasi, penghilangan warna, dan terakhir pengemasan ${ }^{(2,3)}$. Dari proses produksi gula dihasilkan produk samping berupa limbah cair industri gula, limbah padat yang berupa ampas tebu, blotong dan abu pembakaran sisa ampas tebu, limbah gas yang berupa aerosol, dan limbah bahan berbahaya dan beracun (LB3). Besarnya produk samping yang dihasilkan dari kegiatan produksi bergantung pada kapasitas produksi dan produk yang dihasilkan. Dari beberapa produk samping yang dihasilkan dari kegiatan produksi gula, limbah cair adalah salah satu produk samping yang menjadi perhatian dan memerlukan penanganan secara detail. Jika diasumsikan rata-rata kapasitas produksi gula di Indonesia sebesar 6.000 sampai 6.250 TCD (Ton Cane Per Day), akan menghasilkan sekitar 800 sampai 900 $\mathrm{m}^{3} /$ hari limbah cair. Tingginya jumlah limbah cair yang dihasilkan oleh industri gula dikarenakan pemakaian air dalam proses produksi gula sangat tinggi. Untuk memproduksi 1 ton gula diperlukan air hingga $22,5 \mathrm{~m}^{3}$ air $(4,5,6,7)$. Secara terperinci besarnya konsumsi air di industri gula ditunjukkan oleh Tabel 1. 
Tabel 1. Konsumsi air di industri gula

\begin{tabular}{|l|l|}
\hline \multicolumn{1}{|c|}{ Penggunaan air } & \multicolumn{1}{c|}{$\begin{array}{c}\text { Konsumsi } \\
\text { (L air/ ton gula) }\end{array}$} \\
\hline Flume water & $5.000-8.000$ \\
\hline Washing water & $1.500-2.500$ \\
\hline Earth transport water & $150-250$ \\
\hline Ekstraksi jus tebu & $300-400$ \\
\hline Purifikasi jus (sweet water) & 120 \\
\hline Kondensasi & $4.000-6.000$ \\
\hline Steam generation & 40 \\
\hline Cleaning & 20 \\
\hline $\begin{array}{l}\text { Pertukaran ion (thin juice } \\
\text { softening or desugarization } \\
\text { of molasses) }\end{array}$ & $50-130$ \\
\hline $\begin{array}{l}\text { Pendinginan dan } \\
\text { pemompaan }\end{array}$ & $400-5.000$ \\
\hline
\end{tabular}

Dari Tabel 1 dapat diketahui bahwa terdapat beberapa unit produksi yang mengkonsumsi air dan menghasilkan jumlah limbah cair dalam jumlah besar seperti unit pemurnian dan penguapan. Limbah cair yang dihasilkan dari unit tersebut berasal dari boiler, kondensor dan sisa pencucian proses, evaporator, buangan ketel dan peralatan lain, kegiatan pembersihan lantai pabrik, tumpahan nira, tetes dan lain-lain(6). Secara umum, karakteristik limbah air kondensor mengandung senyawa organik yang sangat rendah. Berbeda dengan limbah cair yang berasal dari boiler dan air bekas pencucian mengandung senyawa organik yang tinggi sehingga memerlukan pengolahan terlebih dahulu sebelum dibuang ke badan air maupun digunakan kembali dalam proses produksi.

Pengolahan limbah cair di industri gula secara umum menggunakan metode fisika (primary treatment) dan metode biologi (secondary treatment) tanpa bahan kimia tambahan. Hal ini dikarenakan limbah cair yang dihasilkan oleh industri gula tidak mengandung bahan beracun dan berbahaya (B3). Potensi pencemaran yang terkandung dari limbah yang dihasilkan oleh industri gula hanya berupa tingginya nilai BOD (Biological Oxygen Demand) dan COD (Chemical Oxygen Demand), nitrogen, fosfor dan derajat keasaman $(\mathrm{pH})$. Penggunaan metode fisika dalam pengolahan limbah cair di industri gula bertujuan untuk menghilangkan padatan tersuspensi serta minyak yang terkandung dalam air limbah. Berbeda dengan metode fisika, penerapan metode biologi bertujuan untuk menghilangkan bahan organic biodegradable(8).

Secara operasional pengolahan limbah cair di industri gula dilakukan oleh Instalasi Pengolahan Air Limbah (IPAL) sederhana yang terdiri dari ekualisasi, netralisasi, pra-sedimentasi circular, bak aerasi, secondary clarifier dan sludge drying bed. Adanya unit-unit dalam IPAL yang berbeda-beda mengharuskan pihak industri gula untuk melakukan evaluasi kinerja tiap-tiap unit IPAL yang dimilikinya. Evaluasi unit IPAL dilakukan mulai dari input dimana air mulai masuk kedalam IPAL hingga air limbah dibuang ke lingkungan atau badan air. Evaluasi unit IPAL di indutri gula dapat dilakukan secara teknis terhadap bangunan IPAL beserta efektifitas kinerjanya. Pelaksanaan evaluasi unit IPAL harus dilakukan secara berkala dengan tujuan untuk mengetahui apakah kondisi IPAL yang ada di industri gula memiliki efektifitas kinerja yang sesuai dengan standar atau tidak. Dalam hal ini kualitas air limbah yang dihasilkan harus memenuhi baku mutu yang tertulis dalam Peraturan Menteri Lingkungan Hidup RI No. 5 Tahun 2014 Lampiran XXII Tentang Baku Mutu Bagi Usaha Dan/Atau Kegiatan Industri Gula.

\subsection{Tujuan Penelitian}

Tujuan dari penelitian ini adalah untuk mengetahui efektifitas kinerja unit IPAL industri gula di Kabupaten Kediri dan Kabupaten Sidoarjo pada tahun 2016 dan 2017.

\section{BAHAN DAN METODE}

\subsection{Bahan}

Sampel air limbah diambil dari inlet dan outlet IPAL industri gula di Kabupaten Kediri dan Kabupaten Sidoarjo selama masa giling secara langsung. Masa giling biasanya dimulai dari bulan Mei sampai bulan Oktober setiap tahunnya. Pengambilan sampel air limbah dengan menggunakan water sampler sebanyak $100 \mathrm{ml}$ dan dimasukkan ke dalam botol gelas berwarna gelap sesuai dengan SNI 6989,59: 2008 Bagian 59: Metode Pengambilan Contoh Air Limbah. Selanjutnya sampel diawetkan dan di simpan sesuai dengan Lampiran B SNI 6989.59: 2008.

\subsection{Metode}

Penelitian ini merupakan penelitian komparatif yang bersifat membandingkan efektifitas kinerja IPAL di industri gula di Kabupaten Kediri dan Kabupaten Sidoarjo berdasarkan penurunan parameter kualitas air limbah pada tahun 2016 dan 2017. Selanjutnya air limbah diuji laboratorium sesuai dengan SNI 6989: 2011 tentang Air dan Air Limbah. Beberapa parameter yang menjadi tolok ukur kualitas limbah antara lain debit, $\mathrm{pH}$ (derajat keasaman), COD, BOD, TSS, dan (Total Suspended Solid). Untuk mengetahui kualitas air limbah yang dihasilkan data hasil pengujian laboratorium harus dibandingkan dengan baku mutu air limbah yang sesuai Peraturan Menteri Lingkungan Hidup RI No. 5 Tahun 2014 
Lampiran XXII Tentang Baku Mutu Bagi Usaha Dan/Atau Kegiatan Industri Gula.

Pengujian efektifitas kinerja IPAL yang ada di industri gula dapat diketahui dengan menggunakan Persamaan 1, (9).

Efektifitas $=\frac{s o-s t}{\text { so }} \times 100 \%$

Dari Persamaan 1 data diketahui bahwa nilai efektifitas dinyatakan dalam bentuk prosentase (\%), dimana So merupakan konsentrasi air limbah di inlet dan Si meruapakan konsentrasi air limbah di outlet.

\section{HASIL DAN PEMBAHASAN}

\subsection{Hubungan antara Kapasitas Produksi dengan Limbah Cair yang Dihasilkan di Industri Gula}

Kegiatan produksi di industri ditentukan oleh jenis dan jumlah bahan baku yang selanjutnya diproses dengan metode dan teknologi tertentu sesuai dengan kapasitas produksinya. Bahan baku yang digunakan dalam proses pembuatan gula antara lain tebu sebagai bahan baku utama dan bahan baku pendukung seperti gamping, belerang, asam fosfat dan floculant. Industri gula di Kabupaten Kediri (PG. Kediri) dan Kabupaten Sidoarjo (PG. Sidoarjo) memiliki kapasitas produksi maksimal sebesar 6,200 TCD dan 2.400 TCD. Berdasarkan hasil penelitaian, tahun 2016 dan 2017 kapasitas produksi gula rata-rata di PG. Kediri dan PG. Sidoarjo berturut-turut sebesar 608,71 TCD; 527,33 TCD; 2.097,19 TCD dan 1.902,28 TCD. Secara terperinci produksi gula di kedua industri gula ditunjukkan oleh Tabel 2 .

Tabel 2. Produksi gula tahun 2016-2017

\begin{tabular}{|l|c|c|c|c|}
\hline \multirow{2}{*}{$\begin{array}{c}\text { Data } \\
\text { pro- } \\
\text { duksi }\end{array}$} & \multicolumn{2}{|c|}{2016} & \multicolumn{2}{c|}{2017} \\
\cline { 2 - 5 } & PG. Kediri & $\begin{array}{c}\text { PG. } \\
\text { Sidoarjo }\end{array}$ & $\begin{array}{c}\text { PG. } \\
\text { Kediri }\end{array}$ & $\begin{array}{c}\text { PG. } \\
\text { Sidoarjo }\end{array}$ \\
\hline $\begin{array}{l}\text { Produksi } \\
\text { tebu } \\
\text { (ton/ } \\
\text { tahun) }\end{array}$ & $1.044 .897,4$ & $5.944 .895,8$ & $969.259,0$ & $4.333 .409,9$ \\
\hline $\begin{array}{l}\text { Produksi } \\
\text { gula } \\
\text { (ton/ } \\
\text { tahun) }\end{array}$ & 109.568 .3 & 377.495 .1 & $79.099,4$ & 342.410 .1 \\
\hline
\end{tabular}

Besarnya kapasitas produksi harian industri gula dalam bentuk TCD secara tidak langsung akan berpengaruh terhadap nilai Baku Mutu Air Limbah (BMAL). Dalam Peraturan Menteri Lingkungan Hidup RI No. 5 Tahun 2014 tentang BMAL dan Peraturan Gubernur Jawa Timur No. 52 Tahun 2014 tentang Perubahan Atas Peraturan Gubernur Jawa Timur No. 72 Tahun 2013 tentang Baku Mutu Air Limbah Bagi Industri dan/atau Kegiatan Usaha Lainnya dijelaskan bahwa penentuan bahan pencemar berdasarkan kapasitas produksi/giling harian dalam TCD dan dikelompokkan menjadi 3 (tiga), yaitu (1) industri gula dengan kapasitas kurang dari 2.500 TCD; (2) industri gula dengan kapasitas antara 2.500 TCD sampai 10.000 TCD; dan (3) industri gula dengan kapasitas lebih dari 10.000 TCD. Selain pengelompokan berdasarkan kapasitas produksi untuk industri gula dengan kapsitas kurang dari 2.500 TCD dan antara 2.500 TCD sampai 10.000 TCD pemisahan BMAL juga didasarkan pada 4 (empat) sumber air limbahnya yaitu air limbah proses, air limbah kondensor, air limbah abu ketel dan air limbah gabungan ${ }^{(1,10)}$.

Karakteristik limbah cair yang dihasilkan oleh industri gula tidak terlepas dari jenis dan kapasitas produksi, sehingga tidak terdapat ketentuan baku untuk menghitung jumlah dan debit limbah yang dihasilkan. Karakteristik limbah cair yang dihasilkan oleh kedua industri gula tersebut secara tidak langsung juga digunakan untuk menentukan kualitas limbah yang dihasilkan dan jenis pengolahan yang tepat. Hasil observasi di PG. Kediri dan PG. Sidoarjo menunjukkan bahwa terdapat 4 (empat) jenis dan sumber limbah cair yang berasal dari unit produksi secara keseluruhan (Tabel 3). Selanjutnya keempat jenis limbah tersebut dialirkan melalui saluran pembuangan air limbah (SPAL) yang berbeda dengan tujuan menghindari pencampuran limbah yang akan mempersulit pengolahannya. Secara terperinci skema pengolahan limbah cair di kedua industri gula ditunjukkan oleh Gambar 1.

Tabel 3. Jenis dan sumber limbah cair di industri gula

\begin{tabular}{|l|l|l|}
\hline \multicolumn{1}{|c|}{$\begin{array}{l}\text { Jenis } \\
\text { limbah cair }\end{array}$} & \multicolumn{1}{|c|}{ Sumber limbah } & \multicolumn{1}{c|}{$\begin{array}{c}\text { Karakteristik } \\
\text { limbah }\end{array}$} \\
\hline $\begin{array}{l}\text { Jatuhan } \\
\text { minyak/oli }\end{array}$ & $\begin{array}{l}\text { Mesin-mesin di unit } \\
\text { penggilingan }\end{array}$ & $\begin{array}{l}\text { Bewarna } \\
\text { kehitaman }\end{array}$ \\
\hline Bocoran nira & $\begin{array}{l}\text { Pipa-pipa penyalur nira } \\
\text { (pipa evaporator dan } \\
\text { juice heater) di unit } \\
\text { pemurnian dan } \\
\text { penguapan }\end{array}$ & $\begin{array}{l}\text { Berwarna hijau } \\
\text { kekuningan }\end{array}$ \\
\hline Air abu & $\begin{array}{l}\text { Unit boiler dan wet } \\
\text { scrubber }\end{array}$ & $\begin{array}{l}\text { Berwarna abu- } \\
\text { abu }\end{array}$ \\
\hline $\begin{array}{l}\text { Air jatuhan } \\
\text { kondensor }\end{array}$ & $\begin{array}{l}\text { Kondensor evaporator, } \\
\text { vacuum pan, rotary } \\
\text { vacuum filter, dan air } \\
\text { pendingin boiler. }\end{array}$ & $\begin{array}{l}\text { Memiliki suhu } \\
\text { tinggi mendekati } \\
\text { titik didih }\end{array}$ \\
\hline
\end{tabular}

Jumlah rata-rata limbah cair yang dihasilkan per ton produksi gula oleh kedua industri gula sebesar $0,15 \mathrm{~m}^{3}$. Hal tersebut diperkuat oleh beberapa penelitian yang menyatakan bahwa rata-rata limbah cair yang dihasilkan dari setiap ton gula yang diproduksi berkisar 0,165 sampai $1,1 \mathrm{~m}^{3},(11-14)$. 


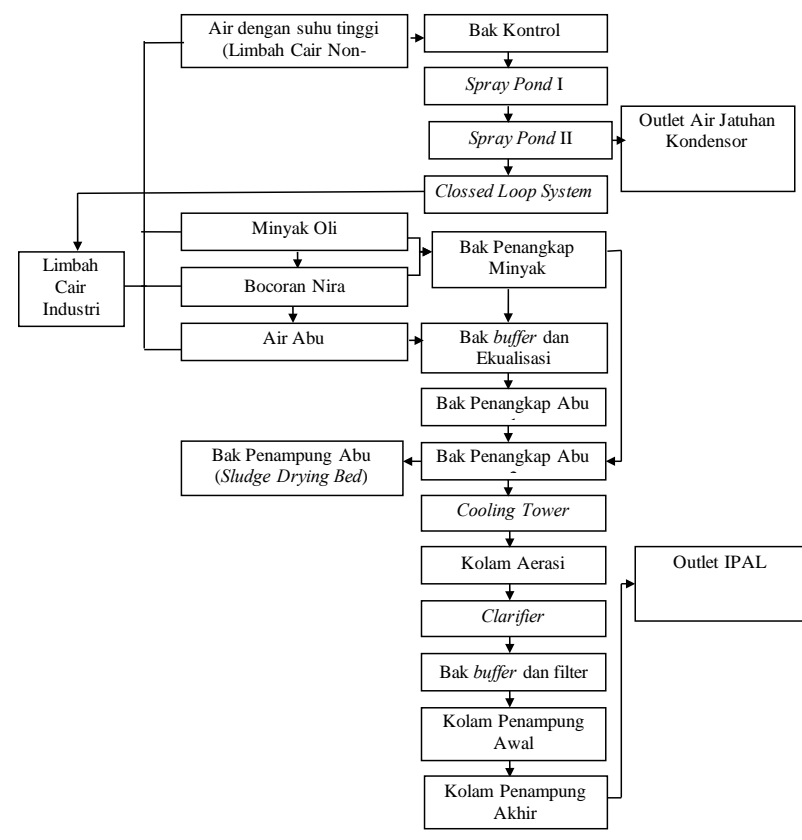

Gambar 1. Skema pengolahan limbah cair di industri gula.

\subsection{Karakteristik Air Limbah di Inlet}

Limbah cair yang dihasilkan oleh industri gula secara umum dapat digolongkan menjadi limbah polutan yang berasal dari proses produksi dan jatuhan kondensor. Limbah jatuhan kondensor menuju unit spray pond untuk diturunkan temperaturnya. Unit spray pond di PG. Sidoarjo terdiri dari 1) bak penampung air jatuhan kondensor yang dilengkapi dengan bak kontrol dan filter, 2) spray pond 1, 3) filter, 4) buffer sebagai penampung air dan 5) spray pond 2, (Gambar 2).

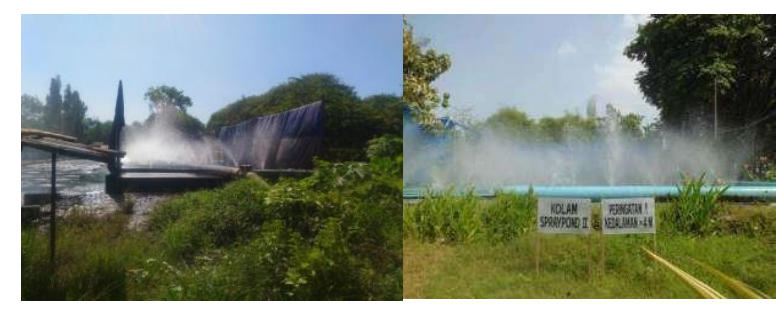

Gambar 2. Unit spray pond 1 dan 2.

Limbah polutan selanjutnya diolah secara langsung di unit IPAL secara terpusat (on side). Sebelum masuk kedalam unit IPAL limbah cair harus diukur karakteristiknya pada bagian inlet. Karakteristik limbah cair yang dihasilkan oleh PG. Kediri dan PG. Sidoarjo pada bagian inlet ditunjukkan oleh Tabel 4.
Tabel 4. Karakteristik limbah cair di inlet

\begin{tabular}{|l|c|c|c|c|c|}
\hline \multirow{2}{*}{$\begin{array}{l}\text { Para- } \\
\text { meter }\end{array}$} & \multirow{2}{*}{\begin{tabular}{c} 
BMAL \\
\cline { 3 - 6 }
\end{tabular}} & $\begin{array}{c}|c| \\
\text { PG. } \\
\text { Kedi } \\
\text { ri }\end{array}$ & $\begin{array}{c}\text { PG. } \\
\text { Sidoarjo }\end{array}$ & $\begin{array}{c}\text { PG. } \\
\text { Kediri }\end{array}$ & $\begin{array}{c}\text { PG. } \\
\text { Sidoarjo }\end{array}$ \\
\hline $\mathrm{pH}$ & $6-9$ & 6,43 & 7,18 & 6,93 & 7,19 \\
\hline $\begin{array}{l}\mathrm{BOD} \\
(\mathrm{mg} / \mathrm{L})\end{array}$ & 60 & $\begin{array}{c}319, \\
71\end{array}$ & 102,69 & 201,37 & 104,65 \\
\hline $\begin{array}{l}\mathrm{COD} \\
(\mathrm{mg} / \mathrm{L})\end{array}$ & 100 & 1.17 & 562,19 & 664,43 & 542,96 \\
\hline $\begin{array}{l}\mathrm{TSS} \\
(\mathrm{mg} / \mathrm{L})\end{array}$ & 50 & 314 & 106,23 & 71,17 & 80,27 \\
\hline
\end{tabular}

* sesuai dengan ketentuan Peraturan Gubernur Jawa Timur No. 52 Tahun 2014

Tabel 4 menunjukkan bahwa karakteristik limbah cair di PG. Kediri dan PG. Sidoarjo memiliki nilai BOD antara 200 sampai $320 \mathrm{mg} / \mathrm{L}$ melebihi ambang batas maksimal BMAL sebesar $60 \mathrm{mg} / \mathrm{L}$, COD antara 540 sampai $1200 \mathrm{mg} / \mathrm{L}$ melebihi ambang batas maksimum BMAL sebesar $100 \mathrm{mg} / \mathrm{L}$ dan TSS anatara 80 sampai $314 \mathrm{mg} / \mathrm{L}$ melebihi ambang batas BMAL sebesar $50 \mathrm{mg} / \mathrm{L}$. Berbeda dengan nilai $\mathrm{pH}$ air limbah yang dihasilkan oleh kedua industri gula telah memenuhi BMAL yaitu antara 6 sampai 9 . Tingginya nilai COD, BOD dan TSS juga dipengaruhi oleh kapasitas produksi. Tahun 2016 PG. Kediri dan PG. Sidoarjo memiliki kapasitas produksi lebih tinggi dari tahun 2017, sehingga secara tidak langsung akan berpengaruh terhadap karakteristik limbah cair yang dihasilkan.

Hampannavar dan Shivayogimath menjelaskan bahwa secara umum karakteristik limbah cair yang dihasilkan oleh industri gula memiliki nilai $\mathrm{pH}$ antara 5,2-6,5, COD antara $1.000-4.340 \mathrm{mg} / \mathrm{L}$, BOD antara $350-2.750 \mathrm{mg} / \mathrm{L}$ dan TSS antara 760-800 mg/L, (15). Berbeda dengan penelitian yang dilakukan oleh Shivayogimath dan Jahagirdar yang menjelaskan bahwa konsentrasi $C O D$ yang terkandung di limbah cair sangat tinggi $(<6,000 \mathrm{mg} / \mathrm{L})$ sehingga memerlukan penanganan khusus melalui electrocoagulation untuk menurunkannya. Besarnya kandungan pencemar dalam limbah cair di industri gula tersebut memiliki nilai pH 5.1, COD $6.400 \mathrm{mg} / \mathrm{L}$, BOD $2.250 \mathrm{mg} / \mathrm{L}$, dan TSS $1.008 \mathrm{mg} / \mathrm{L}$, (16).

\subsection{Karakteristik Air Limbah di Outlet}

Pengolahan air limbah di industri gula bertujuan untuk mengurangi kadar pencemar yang dihasilkan dari proses produksi gula sampai pada ambang batas yang telah ditentukan oleh BMAL sebelum dibuang ke lingkungan maupun dimanfaatkan kembali untuk keperluan pendukung kegiatan di industri gula. Di Propinsi Jawa Timur, BMAL di industri gula diatur dalam Peraturan Gubernur Jawa Timur No. 52 Tahun 
2014 dan Peraturan Menteri Lingkungan Hidup RI No. 5 Tahun 2014. Setelah proses pengolahan air limbah yang dilakukan di unit IPAL diperlukan monitoring dan evaluasi secara berkala pada bagian outlet untuk mengetahui kualitas air limbah hasil olahan dan tingkat kinerja IPAL yang digunakan. Karakteristik air limbah di PG. Kediri dan PG. Sidoarjo pada bagian outlet setelah dilakukan pengolahan air limbah di unit IPAL ditunjukkan oleh Tabel 5.

Tabel 5. Karakteristik limbah cair di outlet

\begin{tabular}{|l|c|c|c|c|c|}
\hline \multirow{2}{*}{$\begin{array}{l}\text { Para- } \\
\text { meter }\end{array}$} & \multirow{2}{*}{\begin{tabular}{c}
$*$ \\
\cline { 3 - 6 }
\end{tabular}} & $\begin{array}{c}\text { PGL } \\
\text { Kediri }\end{array}$ & $\begin{array}{c}\text { PG. } \\
\text { Sidoarjo }\end{array}$ & $\begin{array}{c}\text { PG. } \\
\text { Kediri }\end{array}$ & $\begin{array}{c}\text { PG. } \\
\text { Sidoar- } \\
\text { jo }\end{array}$ \\
\hline $\mathrm{pH}$ & $6-9$ & 7,23 & 6,92 & 7,26 & 6,90 \\
\hline $\begin{array}{l}\mathrm{BOD} \\
(\mathrm{mg} / \mathrm{L})\end{array}$ & 60 & 3,57 & 23,62 & 3,51 & 23,41 \\
\hline $\begin{array}{l}\mathrm{COD} \\
\text { (mg/L) }\end{array}$ & 100 & 14,24 & 98,65 & 12,22 & 95,93 \\
\hline $\begin{array}{l}\mathrm{TSS} \\
\text { (mg/L) }\end{array}$ & 50 & 4,66 & 18,89 & 11,03 & 18,08 \\
\hline
\end{tabular}

${ }^{*}$ Sesuai dengan ketentuan Peraturan Menteri Lingkungan Hidup RI No. 5 Tahun 2014

Tabel 5 menunjukkan bahwa setelah pengolahan air limbah yang dihasilkan oleh PG. Kediri dan PG. Sidoarjo telah memenuhi BMAL sesuai dengan Peraturan Menteri Lingkungan Hidup RI No. 5 Tahun 2014. Hal tersebut menunjukkan bahwa unit IPAL memiliki kinerja yang baik. Untuk mengetahui nilai kinerja IPAL tersebut perlu dilakukan perhitungan nilai efektifitas kinerja untuk setiap parameter air limbah yang dihasilkan oleh industri gula tersebut.

Parameter $\mathrm{pH}$ pada industri gula tidak dapat dilihat nilai keefektifitasannya. Nilai $\mathrm{pH}$ di $\mathrm{PG}$. Kediri dan PG. Sidoarjo baik pada bagian inlet maupun outlet masih menunjukkan nilai netral atau sesuai dengan BMAL yang ditentukan. Namun beberapa penelitian menunjukkan bahwa nilai $\mathrm{pH}$ pada bagian outlet setelah limbah cair di olah dalam IPAL menunjukkan nilai basa atau diatas 7 , yaitu berkisar antara 8.1 sampai 9.5 , (17). Tetapi ada beberapa peneliti yang menyatakan nilai $\mathrm{pH}$ pada bagian outlet setelah limbah cair di olah dalam IPAL bersifat asam berkisar antara 4.4 sampai $6^{(18)}$. Di industri gula $\mathrm{pH}$ air limbah bersifat asam karena penggunaan asam fosfat dan asam sulfat pada proses pemurnian dan penguapan (19). Penurunan $\mathrm{pH}$ yang terjadi di outlet disebabkan oleh efek pengolahan limbah cair secara biologis dengan menggunakan mikrorganisme ${ }^{(20,21)}$. Adanya peningkatan jumlah amoniak yang terkandung dalam air limbah akibat dari penguraian protein dalam proses aerasi berdampak pada penurunan $\mathrm{pH}$ air limbah (diatas nilai 7 netral) dan menurunkan kualitas tanah(22,23).
Nilai BOD pada bagian outlet di PG. Sidoarjo lebih tinggi $600 \%$ bila dibandingkan dengan nilai BOD di PG. Kediri. Hal yang sama juga dapat dilihat dari nilai COD yang menunjukkan PG. Sidoarjo memiliki nilai COD yang lebih tinggi bila dibandingkan dengan PG. Kediri. Nilai BOD dan COD tahun 2016 lebih tinggi dibanding nilai BOD dan COD tahun 2017. Pengukuran nilai $C O D$ ini menunjukkan beban bahan organik dan menjadi indikasi kondisi toxic (racun) yang terkandung dalam air limbah(21,23). Nilai COD yang tinggi $3,140 \mathrm{mg} / \mathrm{L}$ tidak dapat digunakan biji atau tanaman tumbuh akibat rendahnya kadar oksigen untuk mengoksidasi material organik dalam memproduksi karbondioksida dan air(24). Sedangkan BOD menunjukkan jumlah oksigen yang digunakan bakteri untuk menguraikan senyawa organik. Selain dipengaruhi oleh kapasitas produksi nilai BOD juga dipengaruhi oleh debit limbah cair. Berdasarkan data hasil observasi diketahui bahwa besarnya debit limbah cair di PG. Kediri dan PG. Sidoarjo tahun 2016 dan 2017 berturutturut sebesar $467,37 \mathrm{~m}^{3} / \mathrm{hari} ; 424,04 \mathrm{~m}^{3} /$ hari; $1.533,96 \mathrm{~m}^{3} / \mathrm{hari} ;$ dan $1.505 \mathrm{~m}^{3} /$ hari. Hasil observasi BOD yang dilakukan Poddar and Sahu (2017) di outlet IPAL menunjukkan nilai yang bervariasi antara 635 sampai $950 \mathrm{mg} / \mathrm{L}$ bergantung pada jarak alirannya ${ }^{(21)}$.

Nilai TSS menunjukkan jumlah padatan tersuspensi yang mempengaruhi kekeruhan dan transparansi serta berdampak pada intensitas cahaya yang dapat masuk dalam air limbah. Nilai TSS dalam setiap air limbah selalu berbeda-beda bergantung pada jumlah dan kualitas bahan organik dan anorganik dalam bentuk partikel terendapkan, melayang, dan komponen tersuspensi koloid. Tabel 5 menunjukan nilai TSS di PG. Kediri tahun 2016 dan 2017 lebih rendah dari PG. Sidoarjo. Nilai TSS PG. Kediri tahun 2017 meningkat $120 \%$ dari tahun 2016 , dari 4,66 $\mathrm{mg} / \mathrm{L}$ menjadi $11,03 \mathrm{mg} / \mathrm{L}$. Sedangkan di PG. Sidoarjo nilai TSS cenderung tetap hanya terjadi penurunan $0,8 \mathrm{mg} / \mathrm{L}$. Hal ini berarti pada tahun 2017 PG. Sidoarjo terjadi penurunan padatan yang dihasilkan dari proses pengolahan limbah di unit IPAL sebesar $0,008 \%$. semakin tinggi nilai TSS yang terkandung dalam limbah semakin keruh kondisi air limbahnya. Nilai TSS pada outlet di PG. Kediri dan Sidoarjo lebih rendah bila dibandingkan dengan beberapa kajian yang dilakukan oleh Memon et al (2006), Doke et al (2011), Saini and Pant (2014), dan Poddar and Sahu (2017) dengan nilai TSS antara 100 sampai $700 \mathrm{mg} / \mathrm{L}(19,21,23,25)$. 


\subsection{Efektifitas Kinerja IPAL Industri Gula}

Efektifitas kinerja IPAL di PG. Kediri dan PG. Sidoarjo merupakan salah satu indikator keberhasilan kegiatan pengolahan limbah cair. Efektifitas dapat ditentukan dari nilai penurunan konsentrasi pencemar yang terkandung dalam limbah cair. Dalam hal ini tingkat penurunan karakteristik limbah dari inlet sampai ke outlet. Besarnya efektifitas kinerja IPAL di PG. Kediri dan PG. Sidoarjo ditunjukkan oleh Tabel 6.

Tabel 6. Efektifitas pengolahan limbah cair di industri

\begin{tabular}{|l|l|l|l|l|l|}
\hline \multirow{2}{*}{$\begin{array}{c}\text { Para- } \\
\text { meter }\end{array}$} & Satuan & \multicolumn{2}{|c|}{2016} & \multicolumn{2}{c|}{2017} \\
\cline { 3 - 6 } & & $\begin{array}{c}\text { PG. } \\
\text { Kediri }\end{array}$ & $\begin{array}{c}\text { PG. } \\
\text { Sidoarjo }\end{array}$ & $\begin{array}{c}\text { PG. } \\
\text { Kediri }\end{array}$ & $\begin{array}{c}\text { PG. } \\
\text { Sidoarjo }\end{array}$ \\
\hline BOD & $\%$ & 98,88 & 77,00 & 98,26 & 77,63 \\
\hline COD & $\%$ & 98,78 & 82,45 & 98,16 & 82,33 \\
\hline TSS & $\%$ & 98,52 & 82,22 & 84,50 & 77,48 \\
\hline
\end{tabular}

Tabel 6 menunjukkan bahwa nilai efektifitas di PG. Kediri lebih tinggi bila dibandingkan dengan PG. Sidoarjo. Hal ini menunjukkan bahwa penurunan konsentrasi BOD, COD dan TSS melalui pengelolaan limbah cair di unit IPAL berlangsung dengan baik dan sesuai dengan perencanaan alternatif pengolahan air limbahnya. Nilai efektifitas pengolahan limbah cair di PG. Sidoarjo pada tahun 2016 dan 2017 tidak mengalami perbedaan yang signifikan. Nilai efektivitas kinerja IPAL yang berkisar antara 77 sampai $82 \%$ dan dapat digolongkan efektif. Tingkat keefektifitas kinerja IPAL di PG. Sidoarjo dapat dilihat dari penurunan konsentrasi pencemar dari inlet menuju outlet yang sesuai dengan ketentuan BMAL. Begitu pula pada tingkat efektifitas kinerja IPAL PG. Kediri ratarata $98 \%$.

Efektifitas kinerja IPAL dalam menurunkan konsentrasi BOD di PG Kediri tahun 2016 dan 2017 mencapai $98 \%$ lebih tinggi 20\% persen dari kinerja IPAL di PG. Sidoarjo pada tahun yang sama. Selain perbedaan konsentrasi BOD di inlet dan outlet yang lebih tinggi PG. Sidoarjo daripada PG. Kediri. Adanya perbedaan spesifikasi teknis (dimensi dan diffuser) kolam aerasi yang merupakan unit IPAL utama dalam pengolahan limbah secara biologis (secondary treatment) untuk air limbah. Kolam aerasi secara umum berfungsi sebagai tempat berlangsungnya degradasi material organik air limbah oleh bakteri anerobik menjadi material yang lebih sederhana. Dibutuhkan suplai oksigen melalui diffuser dan nutrien yang berupa senyawa nitrogen $(\mathrm{N})$ dan phosphor $(\mathrm{P})$ ke dalam proses aerasi tersebut. Hasil observasi yang dilakukan di kedua industri gula diketahui bahwa dimensi kolam aerasi di PG. Kediri dan PG. Sidoarjo ditunjukkan oleh Tabel 7.
Tabel 7. Dimensi kolam aerasi di PG. Kediri dan PG. Sidoarjo

\begin{tabular}{|l|l|l|l|}
\hline $\begin{array}{c}\text { Detail } \\
\text { spesifikasi }\end{array}$ & \multicolumn{1}{|c|}{ Satuan } & PG. Kediri & $\begin{array}{c}\text { PG. } \\
\text { Sidoarjo }\end{array}$ \\
\hline Panjang & meter & 59 & 58.30 \\
\hline Lebar & meter & 28.8 & 7.5 \\
\hline Kedalaman & meter & 2.5 & 3.5 \\
\hline Diffuser & buah & 180 & 100 \\
\hline
\end{tabular}

Dari Tabel 7 dapat diketahui bahwa volume kolam aerasi di PG. Kediri dan PG. Sidoarjo sebesar $4.248 \mathrm{~m}^{3}$ dan 1.530,375 $\mathrm{m}^{3}$. Sedangkan debit maksimal air limbah di PG. Kediri dan PG. Sidoarjo sebesar $4.000 \mathrm{~m}^{3} /$ hari dan $1200 \mathrm{~m}^{3} /$ hari, maka periode aerasi (HRT) di PG. Kediri dan PG. Sidoarjo selama 25,5 jam dan 30,6 jam. Direktorat Pekerja Umum Cipta Karya menentukan periode aerasi yang baik berkisar antara 18 sampai 36 jam. Selain dipengaruhi oleh periode aerasi efektifitas penurunan konsentrasi BOD juga ditentukan oleh kebutuhan suplai oksigen yang berasal dari blower. Kurangnya suplai oksigen akan menyebabkan mikroorganisme dalam kolam aerasi mati, sehingga akan terjadi kenaikan rasio Food on Microorganism (F/M rasio).

Efektifitas kinerja IPAL dalam menurunkan konsentrasi COD di PG. Kediri dan PG. Sidoarjo pada tahun 2016 dan 2017 berturut-turut sebesar 98,78; 98,16; 82,45; dan 82,23 (Tabel 6). Terjadi perbedaan efektifitas kinerja IPAL sebesar 16\% antara PG. Kediri dengan PG. Sidoarjo dalam menurunkan $C O D$ pada air limbah. COD menunjukkan seberapa banyak senyawa organik yang dapat dioksidasi secara kimia. Dalam air limbah konsentrasi COD menunjukkan ukuran tingkat pencemaran, semakin tinggi nilai COD kebutuah oksigen akan semakin tinggi, sehingga kandungan polutan dalam air limbah semakin tinggi.

Efektifitas kinerja IPAL dalam menurunkan konsentrasi TSS di PG. Kediri pada tahun 2016 lebih tinggi 14\% dari tahun 2017. Tahun 2016 nilai efektifitas sebesar $98,52 \%$ dan tahun 2017 sebesar $84,50 \%$. Sedangkan nilai efektifitas kinerja IPAL dalam menurunkan konsentrasi TSS di PG. Sidoarjo pada tahun 2016 dan 2017 memiliki nilai yang lebih rendah jika dibandingkan dengan PG. Kediri. Selain perbedaan konsentrasi TSS di inlet dan outlet efektifitas penurunan TSS dipengaruhi oleh kinerja unit clarifier. Di industri gula unit clarifier digunakan untuk memisahkan lumpur dengan air limbah dengan cara mengendapkan air limbah secara gravitasi setelah air limbah diolah secara biologi pada kolam aerasi. Perbedaan dimensi clarifier secara tidak langsung juga akan berpengaruh terhadap efektifitas kinerja unit IPAL dalam menurunkan TSS. PG. Kediri memiliki 2 (dua) buah clarifier dengan bentuk tabung berdiameter 8 meter dengan kedalaman 1,5 meter. Berbeda dengan 
PG. Sidoarjo yang hanya memiliki 1 (satu) buah clarifier berbentuk balok dengan dimensi panjang 7,75 meter, lebar 7,75 meter dan kedalaman 4 meter. Waktu pengendapan rata-rata di PG. Kediri dan PG. Sidoarjo ini berkisar antara 2 sampai 6 jam tergantung pada debit limbah yang dihasilkan.

\section{KESIMPULAN}

Karakteristik limbah cair yang dihasilkan oleh industri gula bergantung kepada kapasitas produksi. Karakteristik limbah cair di PG. Kediri baik di inlet dan outlet memiliki nilai lebih rendah bila dibandingkan dengan limbah yang dihasilkan oleh PG. Sidoarjo. Secara umum parameter fisika-kimia air limbah seperti $\mathrm{pH}, \mathrm{BOD}, \mathrm{COD}$, dan TSS air limbah di outlet sebelum dibuang ke lingkungan (badan air) maupun dimanfaatkan kembali telah memenuhi BMAL yang ditentukan oleh Peraturan Gubernur Jawa Timur No. 52 Tahun 2014. Nilai efektifitas kinerja IPAL dalam menurunkan konsentrasi BOD, COD dan TSS PG. Kediri lebih tinggi $16 \%$ bila dibandingkan dengan efektifitas PG. Sidoarjo, sehingga perlu adanya pengkajian kinerja teknis IPAL secara berkala di kedua industri gula tersebut untuk meningkatkan kinerjanya.

\section{DAFTAR PUSTAKA}

1. Kambuaya, B. (2014). Peraturan Menteri Lingkungan Hidup Republik Indonesia Nomor 5 Tahun 2014 tentang Baku Mutu Air Limbah, 1-85.

2. Moerdokusumo, A. (1993). Pengawasan Kualitas dan Teknologi Pembuatan Gula di Indonesia: Institut Teknologi Bandung.

3. Santoso, B. (2011). Proses Pembuatan Gula Dari Tebu pada PG X: Universitas Gunadarma.

4. Bantacut, T., dan Novitasari, D. (2016). Energy and water self-sufficiency assessment of the white sugar production process in Indonesia using a complex mass balance model. Journal of Cleaner Production, 126, 478-492.

5. Morar, F., Rus, D., dan Lung, BI. (2016). The Influence of Sugar-Processing Effects on Water in Treatment Plants. Procedia Technology, 22, 486-492.

6. Rahmani, A. (2019, Monday, 11 Mar 2019). Pengelolaan Air dalam Industri Pangan. Retrieved from https://www.researchgate.net/publication/28 7583632.

7. Ramjeawon, T. (2000). Cleaner Production in Mauritian Cane-Sugar Factories. Journal of Cleaner Production, 8, 503-510.
8. Rais, M. dan Sheoran, A. (2015). Treatment of Sugarcane Industry Effluents. Int Journal of Engineering Research and Applications, 5(1), 11-19.

9. Metcalf, Eddy, Tchobanoglous, G., Burton FL, dan Stensel, H.D. (2003). Wastewater Engineering Treatment and Reuse: McGraw-Hill Companies.

10. Soekarwo. (2014). Peraturan Gubernur Jawa Timur No 52 Tahun 2014 tentang Baku Mutu Air Limbah Bagi Industri dan/atau Kegiatan Usaha Lainnya, 1-15.

11. Cortés, M.G., Verelst, H, Pedraja, R.E., Suárez, E.G. (2011). Water and Wastewater Management in a Sugar Process Production. Paper presented at the 14th Integration, Modelling and Optimisation for Energy Saving and Pollution Reduction.

12. Deshmukh, G., dan Sonaje, N. (2017). Water Conservation in Sugar Industry: A Case Study of Lokmangal Sugar, Ethanol and Co-Generation Industries LTD, Bhandarkavathe. International Journal Of Innovations In Engineering Research And Technology, 4(8), 20-26.

13. Sahu, O. (2018). Assessment of sugarcane industry: Suitability for production, consumption, and utilization. Annals of Agrarian Science, 16(4), 389-395.

14. Sharma, C. dan Kumar, V. (2015). Analysis of the Volume of the Main Water and Wastewater in a Sugar Manufacturing Process followed by the Suggestion Regarding the Reutilization of the Waste Water. International Journal of Current Engineering and Technology, 5(3), 17571761.

15. Hampannavar, U. dan Shivayogimath, C. (2010). Anaerobic treatment of sugar industry wastewater by Upflow anaerobic sludge blanket reactor at ambient temperature. International Journal Of Environment, 1(4), 631-639.

16. Shivayogimath C. dan Jahagirdar R. (2013). Treatment of Sugar Industry Wastewater Using Electrocoagulation Technique. International Journal of Research in Engineering and Technology, 262-265.

17. Akbar, N.M., dan Khwaja, M.A. (2006). Study on Effluents from Selected Sugar Mills in Pakistan: Potential Environmental, Health, and Economic Consequences of an Excessive Pollution Load. (Research report), Islamabad Sustainable Development Policy Institute.

18. Jadhav, P., Vaidya, N., dan Dethe, S. (2013). Characterization and Comparative study of Cane Sugar Industry Waste Water. 
International Journal of Chemical and Physical Sciences, 2(2), 19-25.

19. Saini, S, dan Pant, S. (2014). Physicochemical analysis of Sugar Mill Effluent and their Impact on Changes of Growth of Wheat (Triticum aestivum) and Maize (Zea mays L.). IOSR Journal of Environmental Science, Toxicology and Food Technology.8(4):57-61.

20. Deepthi, T., dan Prabhakaran, J. (2016). Physico-Chemical Analysis Of Sugar Mill Effluents And Its Effect On Seed Germination Of Paddy (Oryza sativa) and Green gram (Vigna radiata). International Journal of Science Engineering and Advance Technology, 4(1), 71-80.

21. Poddar, P.K., dan Sahu, O. (2017). Quality and management of wastewater in sugar industry. Applied Water Science, 7(1), 461468.

22. Agustinus, E.T.S., Sembiring, H., dan Effendi (2014). Aplikasi Material Preservasi Mikroorganisme

(Mpmo)

Dalam
Pemrosesan Limbah Cair Organik Pada Instalasi Pengolahan Air Limbah. Jurnal Riset Geologi dan Pertambangan, 24(1), 65-76.

23. Doke, K.M., Khan, E.M., Rapolu, J., Shaikh, A. (2011). Physico-Chemical Analy- Sis Of Sugar Industry Effluent And Its Effect On Seed Germination Of Vigna Angularis, Vigna Cylindri- Cal And Sorghum Cernum. Annals of Environmental Science, 5, 7-11.

24. Samuel, S, dan Muthukkaruppan S. (2011). Physico-Chemical Analysis of Sugar Mill Effluent, Contaminated Soil and its Effect on Seed Germination of Paddy (Oryza sativa L.). International Journal of Pharmaceutical \& Biological Archives, 2(5), 1469-1472.

25. Memon, A.R., Soomro, S.A., Anshari, A.K. (2006). Sugar Industry EffluentCharacteristics and Chemical Analysis. J App Env Sci, 1(2), 152-157. 